\title{
Promoter polymorphisms of the CD14 gene in Italian patients with coeliac disease
}

\author{
M Boniotto, L Braida, A Ventura, S Percopo, A Amoroso, S Crovella
}

J Med Genet 2003;40:e108 (http://www.jmedgenet.com/cgi/content/full/40/9/e108)

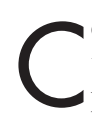
oeliac disease (CD) is an autoimmune enteropathy triggered by ingestion of wheat gluten or related protein from rye and barley, and is one of the most frequently occurring, treatable, lifelong disorders. ${ }^{12}$ Undetected or untreated CD may cause other, more severe, complications later, such as autoimmune diseases, osteoporosis, neurological disorders, and infertility. ${ }^{34}$

Several studies have shown CD clusters in families with a sibling relative risk of 20-60 and high concordance between monozygotic twins $(75 \%),{ }^{5-8}$ which indicates a strong genetic component to coeliac disease. As expected in complex autoimmune diseases, human leukocyte antigen (HLA) linked genes are the main genetic factor involved in CD. More than $90 \%$ of patients suffering from CD share the major histocompatibility complex II class HLA-DQ2 haplotype. Most of the remainder present HLA-DQ8. However, there are patients who present neither HLA-DQ8 nor HLA-DQ2 on their antigen-presenting cells. These genetic findings strongly indicate the involvement of other genes in the pathogenesis of coeliac disease. So far, various genome-wide linkage analyses have been performed in order to identify non-HLA linked genes responsible for CD. A recent study by Greco et al. ${ }^{9}$ on Italian coeliac families demonstrated the existence of a genetic risk factor on chromosome 5 (5q31-33), which has been reported in other linkage studies in different populations. $^{1011}$ This genomic region contains several candidate genes for $\mathrm{CD}$, including the interleukin $(I L 12 B)$ gene, the polymorphisms of which do not seem to be associated with $\mathrm{CD},{ }^{12}$ and the gene encoding for CDI4. ${ }^{13}$

CD14 is a multifunctional receptor involved in the innate immune response. In fact, it is thought to be one of the most important receptors for lipopolysaccharide and other bacterial wall-derived components. ${ }^{14-16}$ However it is well known that CD14 has several other functions, ${ }^{17} 18$ including the clearance of apoptotic cells. ${ }^{19}$ It is constitutively expressed, primarily on the surface of monocytes, macrophages, and neutrophils (mCD14); a soluble form, sCD14, has been isolated from serum and is derived both from secretion of CD14 and from enzymatically cleaved glycosyl-phosphatidylinositol anchored mCD14..$^{21}$

The serum levels of CD14, and thus the levels of mCD14, are genetically regulated. Four single nucleotide polymorphisms have been identified in the promoter region of the gene, and are thought to regulate the CD14 gene expression.22 Recently, different studies have correlated a $\mathrm{C} \rightarrow \mathrm{T}$ transition at position -159 in the promoter region of the CDI4 gene, with an increased risk of developing Crohn's disease and ulcerative colitis, ${ }^{23}{ }^{24}$. Furthermore, a study by Holla et al. ${ }^{25}$ demonstrated an association between a $\mathrm{G} \rightarrow \mathrm{T}$ transversion at position -1359 and the severity of periodontitis.

In our study the frequency of the two promoter polymorphisms was assessed in three selected populations in order to explore the influence of CDI4 in coeliac disease, because the CD14 gene is located in a "hotbed" region for CD and is involved in the clearance of apoptotic cells, which

\section{Key points}

- Coeliac disease is a gluten dependent, immune mediated enteropathy caused, in genetically susceptible individuals, by a T-cell response to a new epitope generated by the transglutaminase-driven deamination of dietary gliadin. This disease is one of the most common multifactorial autoimmune disorders in the white population (1 in 200 individuals).

- CD14 is a multifunctional receptor involved in innate immune response. In fact, it is thought to be one of the most important receptor for lipopolysaccharide and other bacterial wall-derived components. However, it is well known that CDI 4 has several other functions, including the clearance of apoptotic cells.

- As the CD14 gene is located in a "hotbed" region for $C D$ and is involved in the clearance of apoptotic cells, the aim of this study was to assess the frequency of two promoter polymorphisms in three selected populations in order to explore the influence of CDI4 in this common autoimmune disorder.

- In our study the allelic and genotype frequencies of $\mathrm{C}(-159) \mathrm{T}$ did not differ among 115 coeliac patients carrying the typical HLA haplotype (DQ2 or DQ8), 37 coeliac patients with an atypical HLA haplotype, and 180 selected healthy controls of the same ethnic origin. There was a significant skewing in coeliac patients with for the genotype frequencies at position - 1359 compared with healthy controls. This difference is mainly due to the higher frequency of $(-1359) \pi$ subjects in coeliac patients carrying the atypical HLA haplotype.

- Several hypotheses could explain the involvement of CD14 in coeliac disease; our findings show the importance of apoptosis regulation. Furthermore, they indicate that the genes encoding proteins, which play a key role in this process, are potential candidates for CD.

could be important in $\mathrm{CD}$, as already demonstrated by the findings of Boniotto et al. ${ }^{26}$

\section{METHODS}

\section{Patients and controls}

For this study 115 Italian coeliac patients with typical HLA haplotypes (either DQ2 or DQ8), 37 Italian coeliac patients with atypical HLA haplotypes, and 180 pan-ethnic controls (healthy blood donors with no history of either gastrointestinal or autoimmune diseases) were enrolled. Diagnosis of coeliac disease was performed following the ESPGHAN 
indications. ${ }^{27}$ The study was approved by the ethics committee at the Burlo Garofolo Children's Hospital, Trieste. The importance of a positive result was explained to all participants, and verbal consent was obtained from the patients.

\section{14 genotyping}

DNA was extracted from peripheral whole blood using standard laboratory protocols. ${ }^{28}$

The detection of the bi-allelic polymorphism at position -159 was performed following the PCR-RFLP technique already described by Baldini et al. ${ }^{29}$

The detection of the bi-allelic polymorphism at position -1359 was performed with a modified version of the PCRRFLP technique described by Holla et al. ${ }^{25}$ Briefly, PCR was performed with the forward primer $5^{\prime}$ AGCACTTTGAGAGGCCAAGG-3' and the reverse primer $5^{\prime}$ CCACATCCCTAGACCTCTGGG-3', both designed on the basis of the published CDI4 human sequence with the software Primer Express 1.5 (Applied Biosystems, Foster City, CA, USA). After an initial denaturation step at $95^{\circ} \mathrm{C}$ for $10 \mathrm{~min}, 35$ cycles with a denaturation step at $95^{\circ} \mathrm{C}$ for $30 \mathrm{~s}$, an annealing step at $62^{\circ} \mathrm{C}$ for $30 \mathrm{~s}$, and an elongation step at $72^{\circ} \mathrm{C}$ for $30 \mathrm{~s}$ were carried out. The PCR reaction mix was $1.5 \mathrm{mmol} / \mathrm{l}$ $\mathrm{MgCl}_{2}, 800 \mu \mathrm{mol} / \mathrm{l} \mathrm{dNTPs}, 200 \mu \mathrm{mol} / \mathrm{l}$ for each primer and contained $1 \mathrm{U}$ of AmpliTaq Gold (Applied Biosystems). PCR products were digested for $2 \mathrm{~h}$ at $37^{\circ} \mathrm{C}$ with the endonuclease FokI (New England Biolabs, Beverly, MA, USA) and subsequently separated on a $2 \%$ agarose gel. The G allele showed one fragment of $303 \mathrm{bp}$, while the $\mathrm{T}$ allele showed two fragments of 215 and $88 \mathrm{bp}$.

\section{Statistical analysis}

Gene frequencies were calculated from the observed number of genotypes. The significance of differences in allelic frequencies was calculated by Fisher's exact test. To test the significance of differences in genotype frequencies a $\chi^{2}$ test was used. Holm's correction for multiple tests was performed and only corrected $\mathrm{p}$ values $\left(\mathrm{p}_{\text {corr }}\right)<0.05$ were considered to be significant. All the statistical analyses were carried out with SPSS software (Version 6.1.3; SPSS Inc., Chicago, IL, USA).

\section{RESULTS}

Allelic frequencies and genotype frequencies for the position -159 in the three populations studied are shown in Table 1. The frequency of the $(-159)$ C allele was $53 \%, 46 \%$, and $50 \%$ in typical HLA coeliac patients, atypical HLA coeliac patients, and healthy controls, respectively. No differences were observed in genotype frequencies between the three populations.

Table 2 shows the allelic and genotype frequencies for the $\mathrm{G}$ to $\mathrm{T}$ transversion at position -1359 . The frequency of the $(-1359) \mathrm{G}$ allele did not differ in the three populations; it was $80 \%$ in typical HLA coeliac patients, $77 \%$ in atypical HLA coeliac patients, and $84 \%$ in healthy controls (Fisher's exact test, $p=0.631$ for typical compared with atypical HLA coeliac patients; $\mathrm{p}=0.251$ for typical HLA coeliac patients compared with healthy controls, and $p=0.172$ for atypical HLA coeliac patients compared with healthy controls). No differences were observed in genotype frequencies when healthy controls and typical HLA coeliac patients were compared $\left(\chi^{2}=4.19\right.$, $\mathrm{p}=0.123)$. However an increased frequency of $(-1359) \mathrm{TT}$ homozygotes were observed in the latter population (odds ratio TT $v$ GT and GG genotypes: $3.82 ; 95 \%$ confidence interval (CI) 0.97 to 15.10 ). In fact the frequencies of $(-1359) \mathrm{GG},(-1359) \mathrm{GT}$, and $(-1359) \mathrm{TT}$ genotypes were $70 \%, 28 \%$, and $2 \%$ in controls, and $67 \%, 27 \%$, and $6 \%$ in typical HLA coeliac patients, respectively. The genotype
Table 1 Allele and genotype frequencies for the $G$ to $T$ transition at position - 159 in the promoter region of the CD14 gene

\begin{tabular}{|c|c|c|c|}
\hline \multirow[b]{2}{*}{ Base } & \multicolumn{2}{|c|}{ Coeliac patients } & \multirow[b]{2}{*}{$\begin{array}{l}\text { Healthy controls } \\
(\mathrm{n}=180)\end{array}$} \\
\hline & $\begin{array}{l}\text { HLA- DQ2 or } \\
\text { DQ-8 } n=115)\end{array}$ & $\begin{array}{l}\text { Neither HLA- DQ2 } \\
\text { nor DQ-8 }(n=37)\end{array}$ & \\
\hline${ }^{*} \mathrm{C}$ & $\begin{array}{l}0.53 \\
123 / 230\end{array}$ & $\begin{array}{l}0.46 \\
34 / 74\end{array}$ & $\begin{array}{l}0.50 \\
181 / 360\end{array}$ \\
\hline $\mathrm{T}$ & $\begin{array}{l}0.47 \\
107 / 230\end{array}$ & $\begin{array}{l}0.54 \\
40 / 74\end{array}$ & $\begin{array}{l}0.50 \\
179 / 360\end{array}$ \\
\hline$\S \mathrm{C} / \mathrm{C}$ & $\begin{array}{l}0.33 \\
38 / 115\end{array}$ & $\begin{array}{l}0.24 \\
9 / 37\end{array}$ & $\begin{array}{l}0.27 \\
48 / 180\end{array}$ \\
\hline$C / T$ & $\begin{array}{l}0.41 \\
47 / 115\end{array}$ & $\begin{array}{l}0.43 \\
16 / 37\end{array}$ & $\begin{array}{l}0.47 \\
85 / 180\end{array}$ \\
\hline$T / T$ & $\begin{array}{l}0.26 \\
30 / 115\end{array}$ & $\begin{array}{l}0.33 \\
12 / 37\end{array}$ & $\begin{array}{l}0.26 \\
47 / 180\end{array}$ \\
\hline
\end{tabular}

*Allelic frequency (Fisher's exact test): typical $v$ atypical HLA coeliac patients: $p=0.320$; typical HLA coeliac patients $v$ healthy controls: $p=0.500$; atypical HLA coeliac patients $v$ healthy controls: $p=0.581$. $\S$ Genotype frequency $(3 \times 2$ contingency tables): typical $v$ atypical HLA coeliac patients: $\chi^{2}=1.13, p=0.567$; typical HLA coeliac patients $v$ healthy controls: $\chi^{2}=1.61, p=0.446$; atypical HLA coeliac patients $v$ healthy controls: $\chi^{2}=0.62, p=0.733$.

Table 2 Allele and genotype frequencies for the $G$ to $T$ transversion at position -1359 in the promoter region of the CD14 gene

\begin{tabular}{llll}
\hline & \multicolumn{2}{l}{ Coeliac patients } & \\
\cline { 2 - 3 } Base & $\begin{array}{l}\text { HLA- DQ2 or } \\
\text { DQ-8 } \mathbf{n}=115)\end{array}$ & $\begin{array}{l}\text { Neither HLA- DQ2 } \\
\text { nor DQ-8 }(\mathbf{n}=\mathbf{3 7})\end{array}$ & $\begin{array}{l}\text { Healthy controls } \\
(\mathbf{n}=180)\end{array}$ \\
\hline${ }^{*} \mathrm{G}$ & 0.80 & 0.77 & 0.84 \\
& $185 / 230$ & $57 / 74$ & $304 / 360$ \\
$\mathrm{~T}$ & 0.20 & 0.23 & 0.16 \\
& $45 / 230$ & $17 / 74$ & $56 / 360$ \\
$\S \mathrm{G} / \mathrm{G}$ & 0.67 & 0.67 & 0.70 \\
$\mathrm{G} / \mathrm{T}$ & $77 / 115$ & $25 / 37$ & $127 / 180$ \\
$\mathrm{~T} / \mathrm{T}$ & 0.27 & 0.19 & 0.28 \\
& $31 / 115$ & $7 / 37$ & $50 / 180$ \\
& 0.06 & 0.14 & 0.02 \\
\hline
\end{tabular}

*Allelic frequency (Fisher's exact test): typical $v$ atypical HLA coeliac patients: $p=0.631$; typical HLA coeliac patients $v$ healthy controls: $\mathrm{p}=0.251$; atypical HLA coeliac patients $v$ healthy controls: $p=0.172$. $\S$ Genotype frequency $(3 \times 2$ contingency tables): typical HLA coeliac patients $v$ atypical HLA coeliac patients: $\chi^{2}=2.680, p=0.262$; typical HLA coeliac patients $v$ healthy controls: $\chi^{2}=4.19, p=0.123$; atypical HLA coeliac patients $v$ healthy controls: $\chi^{2}=12.640, p=0.0018$.

frequencies in the atypical HLA coeliac patients were $67 \%$, $19 \%$, and $14 \%$ for the genotype $(-1359) \mathrm{GG},(-1359) \mathrm{GT}$, and $(-1359)$ TT, respectively. This distribution did not differ when compared with that of typical HLA coeliac patients $\left(\chi^{2}=2.680, p=0.262\right)$, but it was significantly different from that of the healthy controls $\left(\chi^{2}=12.640, p=0.0018\right.$, $\left.\mathrm{p}_{\text {corr }}<0.05\right)$, mainly due to the difference in the frequency of $(-1359)$ TT homozygous individuals. Odds ratio for TT genotype in atypical HLA coeliac patients was 9.22 (95\% CI 2.10 to 40.50$)$.

\section{DISCUSSION}

Coeliac disease is one of the most common multifactorial autoimmune disorders in the white population ( 1 in 200 individuals). The principal genetic (HLA-linked genes) and environmental (wheat gluten) factors responsible for CD are well known, but few data are available for non-HLA-linked genes. 
In this case-control study we have assessed the frequency of two polymorphisms in the promoter region of the CDI4 gene, which regulate the expression of the protein in three selected populations.

LeVan et al..$^{30}$ demonstrated that $(-159) \mathrm{T}$ allele promotes CD14 gene transcription and that homozygous subjects for this allele have increased CDI4 serum levels. ${ }^{29}$ In our study the allelic and genotype frequencies of $\mathrm{C}(-159) \mathrm{T}$ did not differ betwen the 115 coeliac patients carrying the typical HLA haplotype (DQ2 or DQ8), the 37 coeliac patients with an atypical HLA haplotype, and the 180 selected healthy controls of the same ethnic origin. Interestingly, there was a significant skewing in coeliac patients with atypical HLA for the genotype frequencies at position - 1359 compared with healthy controls. This difference is mainly due to the higher frequency of $(-1359)$ TT subjects in coeliac patients carrying the atypical HLA haplotype. The frequency of $(-1359)$ TT patients was also greater in coeliac patients with typical HLA, even though our results do not reach statistical significance. As demonstrated by Vercelli et $a l^{31}(-1359)$ TT subjects have lower serum levels of CDI4. The odds ratio of developing coeliac disease for $(-1359)$ TT atypical HLA coeliac patients is 9.22 (95\% CI 2.10 to 40.50 ).

Several hypotheses could explain the involvement of CD14 in coeliac disease. Firstly, individuals with low levels of sCD14, and thus mCD14, might be more prone to Gramnegative bacterial infections. These infections may disrupt the permeability of intestinal epithelia, leading to an increased concentration of gluten in the lamina propria, where most of the gluten-reactive lymphocytes are localised. Such individuals may be more susceptible to developing coeliac disease. Unfortunately, no studies linking the $\mathrm{G}(-1359) \mathrm{T}$ polymorphism to a risk of infection have been carried out. Moreover, a recent study by Agnese $e a^{32}$ showed a significant correlation between TLR4 polymorphisms and an augmented risk of gram negative bacterial infection: no association was found between $\mathrm{CD} 14 \mathrm{C}(-159) \mathrm{T}$ polymorphism and the incidence of infection or patients' outcome.

Another possibility, and in our opinion the most interesting, may derive from the role of CD14 in apoptosis regulation. The defective clearance and removal of apoptotic cells has been closely linked to autoimmune and persistent inflammatory diseases. ${ }^{33}$ Recently Boniotto et al ${ }^{26}$ found a significant association between allelic variants within the first exon of the mannose-binding lectin $2(M B L 2)$ gene and an increased risk of $C D$, and discussed the importance of mannose-binding lectin in the clearance and removal of apoptotic cells. Several studies demonstrate that CD14 is able to bind several apoptotic-cell-associated molecular patterns (ACAMPs), ${ }^{19} 34{ }^{35}$ such as ICAM-3 on apoptotic leukocytes, ${ }^{36}$ and may either act as a phagocyte pattern-recognition receptor or bind directly to ACAMPs to initiate engulfment of apoptotic cells. Moreover, it is known that MBL binds to apoptotic cells and initiates their uptake by interacting with phagocyte calreticulin receptors on the macrophage cell surfaces. ${ }^{37}$ In the same way, CD14 is expressed mainly on the surface of these "professional" phagocytes that, unlike dendritic cells, are also able to present apoptotic-cell-derived antigens to $\mathrm{T}$ cells in a tolerogenic manner, providing functional inactivation or deletion of potentially autoreactive T cells. ${ }^{38}{ }^{39}$ Furthermore, sCDI4 is able to bind and switch off activated $\mathrm{T}$ cells. ${ }^{40}$ Taken together, these data explain why subjects with lower levels of CD14 (both mCDI4 and sCD14) are more prone to develop autoimmune diseases, such as CD.

At the moment, linkage disequilibrium of the $\mathrm{G}(-1359) \mathrm{T}$ allele with the real causative gene for $\mathrm{CD}$ in the genomic region 5q31-33 cannot be excluded.

In conclusion, a significant association between $(-1359) \mathrm{TT}$ genotype and an increased risk for CD was shown in coeliac patients with atypical HLA haplotype. There was a positive trend for a higher frequency of $(-1359)$ TT individuals in typical HLA coeliac patients, although it did not reach statistical significance. To our knowledge, this is the first study that has found a significant association between $C D$ and a polymorphism in a gene located in the candidate genomic region 5q31-33.

Finally, our findings demonstrate the importance of apoptosis regulation. They indicate that the genes encoding proteins, which play a key role in this process, are potential candidates for CD. A larger cohort of typical HLA coeliac patients should probably be studied, and functional studies carried out, to clarify the role of CD14 in coeliac disease.

\section{ACKNOWLEDGEMENTS}

This work was supported by a grant (PRIN 2002) from the Italian Ministry of Research. Michele Boniotto is the recipient of a long-term fellowship from Trieste University. The authors wish to thank Dr Kevin Danton for his help in revising the manuscript.

\section{Authors' affiliations}

M Boniotto, L Braida, A Ventura, A Amoroso, S Crovella, Dipartimento di Scienze della Riproduzione e dello Sviluppo, Universita' di Trieste, Via dell'Istria 65/1, 34137 Trieste, Italy

S Percopo, Dipartimento di Pediatria, Universita' di Napoli Federico II, Via Pansini 5, 80131 Napoli, Italy

A Amoroso, S Crovella, Servizio di Genetica, IRCCS Burlo Garofolo, Via dell'Istria 65/1, 34137 Trieste, Italy

Correspondence to: Sergio Crovella, Dipartimento di Scienze, della Riproduzione e dello Sviluppo, University of Trieste, Via dell'Istria 65/1, 34137 Trieste, Italy; crovella@burlo.trieste.it

\section{REFERENCES}

1 Korponay-Szabo IR, Kovacs JB, Czinner A, et al. High prevalence of silent celiac disease in preschool children screened with $\operatorname{lgA} / \operatorname{lgG}$ antiendomysium antibodies. J Pediatr Gastroenterol Nutr 1999;28:26-30.

2 Meloni G, Dore A, Fanciulli G, et al. Subclinical coeliac disease in schoolchildren from northern Sardinia. Lancet 1999;353:37.

3 Ventura A, Magazzu G, Greco L. Duration of exposure to gluten and risk for autoimmune disorders in patients with celiac disease. SIGEP Study Group for Autoimmune Disorders in Celiac Disease. Gastroenterology 1999; 117:297-303.

4 Not T, Tommasini A, Tonini G, et al. Undiagnosed coeliac disease and risk of autoimmune disorders in subjects with Type I diabetes mellitus. Diabetologia $2001 ; 44: 151-5$

5 Risch N. Assessing the role of HLA-linked and unlinked determinants of disease. Am J Hum Genet 1987;40:1-14.

6 Petronzelli F, Bonamico M, Ferrante P, et al. Genetic contribution of the HLA region to the familial clustering of coeliac disease. Ann Hum Genet 1997;61 (Pt 4):307-17.

7 Bevan S, Popat S, Braegger CP, et al. Contribution of the MHC region to the familial risk of coeliac disease. J Med Genet 1999;36:687-90.

8 Greco L, Romino R, Coto I, et al. The first large population based twin study of coeliac disease. Gut 2002;50:624-8.

9 Greco L, Babron MC, Corazza GR, et al. Existence of a genetic risk factor on chromosome $5 q$ in Italian coeliac disease families. Ann Hum Genet $2001 ; 65: 35-41$

10 Naluai AT, Nilsson S, Gudjonsdottir AH, et al. Genome-wide linkage analysis of Scandinavian affected sib-pairs supports presence of susceptibility loci for celiac disease on chromosomes 5 and 11. Eur J Hum Genet 2001;9:938-44.

11 Liu J, Juo SH, Holopainen P, et al. Genomewide linkage analysis of celiac disease in Finnish families. Am J Hum Genet 2002;70:51-9.

12 Louka AS, Torinsson Naluai A, D'Alfonso S, et al. The IL12B gene does not confer susceptibility to coeliac disease. Tissue Antigens 2002;59:70-2.

13 Goyert SM, Ferrero E, Rettig WJ, et al. The CD14 monocyte differentiation antigen maps to a region encoding growth factors and receptors. Science 1988;239:497-500.

14 Wright SD, Ramos RA, Tobias PS, et al. CD14, a receptor for complexes of lipopolysaccharide (LPS) and LPS binding protein. Science 1990;249:1431-3.

15 Cleveland MG, Gorham JD, Murphy TL, et al. Lipoteichoic acid preparations of Gram-positive bacteria induce interleukin-12 through a CD14-dependent pathway. Infect Immun 1996;64:1906-12.

16 Yoshida A, Koide Y. Arabinofuranosyl-terminated and mannosylated lipoarabinomannans from Mycobacterium tuberculosis induce different levels of interleukin-12 expression in murine macrophages. Infect Immun 1997;65:1953-5. 
17 Grunwald U, Fan X, Jack RS, et al. Monocytes can phagocytose Gramnegative bacteria by a CD14-dependent mechanism. J Immunol 1996; 157:4119-25.

18 Amano S, Kawakami K, Iwahashi $\mathrm{H}$, et al. Functional role of endogenous CD14 in lipopolysaccharide-stimulated bone resorption. J Cell Physiol 1997:173:301-9.

19 Devitt A, Moffatt OD, Raykundalia C, et al. Human CD14 mediates recognition and phagocytosis of apoptotic cells. Nature 1998;392:505-9.

20 Ulevitch RJ, Tobias PS. Receptor-dependent mechanisms of cell stimulation by bacterial endotoxin. Annu Rev Immunol 1995;13:437-57.

21 Haziot $A$, Chen $S$, Ferrero $E$, et al. The monocyte differentiation antigen, CD14, is anchored to the cell membrane by a phosphatidylinositol linkage. $J$ Immunol 1988; 141:547-52.

22 Baldini M, Kabesch M, Graves PE, et al. Detection of four novel polymorphisms in the CD14 promoter and association of their haplotypes with total serum IgE levels. American Thoracic Society Meeting, Toronto.

23 Klein W, Tromm A, Griga T, et al. A polymorphism in the CD14 gene is associated with Crohn disease. Scand J Gastroenterol 2002;37:189-91.

24 Obana N, Takahashi S, Kinouchi Y, et al. Ulcerative colitis is associated with a promoter polymorphism of lipopolysaccharide receptor gene, CD14. Scand J Gastroenterol 2002;37:699-704.

25 Holla LI, Buckova D, Fassmann A, et al. Promoter polymorphisms in the CD14 receptor gene and their potential association with the severity of chronic periodontitis. J Med Genet 2002;39:844-8.

26 Boniotto M, Braida L, Spano A, et al. Variant mannose-binding lectin alleles are associated with celiac disease. Immunogenetics 2002;54:596-8

27 Walker-Smith JA, Guandalini S, Schmitz J, et al. Revised criteria for diagnosis of coeliac disease: report of working group of European Society of Paediatric Gastroenterology and Nutrition. Arch Dis Child 1990;65:909-11.

28 Sambrook J, Fritsch EF, Maniatis T. In: Molecular Cloning: A Laboratory Manual. New York: Cold Spring Harbor Laboratory Press, 1989.

29 Baldini M, Lohman IC, Halonen M, et al. A polymorphism in the 5' flanking region of the CD14 gene is associated with circulating soluble CD14 levels and with total serum immunoglobulin E. Am J Respir Cell Mol Biol 1999;20:976-83.
30 LeVan TD, Bloom JW, Bailey TJ, et al. A common single nucleotide polymorphism in the CD14 promoter decreases the affinity of Sp protein binding and enhances transcriptional activity. J Immunol 2001; 167:5838-44.

31 Vercelli D, Baldini M, Martinez F. The monocyte/lgE connection: may polymorphisms in the CDI 4 gene teach us about lgE regulation? Int Arch Allergy Immunol 2001;124:20-4.

32 Agnese DM, Calvano JE, Hahm SJ, et al. Human toll-like receptor 4 mutations but not CD14 polymorphisms are associated with an increased risk of Gram-negative infections. J Infect Dis 2002:186:1522-5.

33 Taylor PR, Carugati A, Fadok VA, et al. A hierarchical role for classical pathway complement proteins in the clearance of apoptotic cells in vivo. J Exp Med 2000;192:359-66.

34 Schlegel RA, Krahling S, Callahan MK, et al. CD14 is a component of multiple recognition systems used by macrophages to phagocytose apoptotic lymphocytes. Cell Death Differ 1999;6:583-92.

35 Fadok VA, Warner ML, Bratton DL, et al. CD36 is required for phagocytosis of apoptotic cells by human macrophages that use either a phosphatidylserine receptor or the vitronectin receptor (alpha $\mathrm{v}$ beta 3). J Immunol 1998;161:6250-7.

36 Moffatt OD, Devitt A, Bell ED, et al. Macrophage recognition of ICAM-3 on apoptotic leukocytes. J Immunol 1999;162:6800-10.

37 Ogden CA, deCathelineau A, Hoffmann PR, et al. Clq and mannose binding lectin engagement of cell surface calreticulin and CD91 initiates macropinocytosis and uptake of apoptotic cells. J Exp Med 2001; 194:781-95.

38 Albert ML, Sauter B, Bhardwaj N. Dendritic cells acquire antigen from apoptotic cells and induce class I-restricted CTLs. Nature 1998;392:86-9.

39 Ronchetti A, Rovere P, lezzi G, et al. Immunogenicity of apoptotic cells in vivo: role of antigen load, antigen-presenting cells, and cytokines. J Immunol 1999; 163:130-6.

40 Rey Nores JE, Bensussan A, Vita N, et al. Soluble CD14 acts as a negative regulator of human $\mathrm{T}$ cell activation and function. Eur $\mathrm{J}$ Immunol 1999;29:265-76. 